\title{
Sustainability 2030: a policy perspective from the University Vocational Awards Council
}

\begin{abstract}
Purpose: The policy and practice sphere of higher education, skills and work-based learning has become increasingly problematic in the last few years, and the extent to which sustainability and sustainable development are embedded in policy and practice spaces is a cause for concern. This paper posits a policy perspective from the University Vocational Awards Council (UVAC), the national representative organisation for universities committed to the vocational agenda and an independent voice in the sphere of higher education, skills and work-based learning.
\end{abstract}

Design/methodology/approach: This paper is a reflective policy and practice piece which draws on the latest policy moves by the UK government and associated organisations and engages the latest literature to examine the issues in policy and practice that need to be tackled.

Findings: This paper argues for a greater integration of sustainable development into higher education, skills and work-based learning policy and practice, and specifically in relation to (1) creating inclusive workplaces, (2) promoting social mobility, (3) a balanced approach to productivity, health and wellbeing, and (4) embedding educational approaches and methods which promote inequality in workplaces.

Originality/value: The paper is the only UK policy perspective explicitly dedicated to sustainability and sustainable development in the context of the sphere of higher education, skills and work-based learning. Although it is focused on UK policy context, it will be of interest to international readers wishing to learn about UK developments and the sustainable development challenges in relation to its apprenticeship, technical and vocational education system. 


\section{Introduction}

The national landscapes of practice for the sphere of higher education, skills and work-based learning has become particularly volatile, uncertain, complex and ambiguous space in recent years. Against a backdrop of broad political changes and turmoil, the UK government has forged ahead with educational reform which is shaking up a national picture with a view to generate longer term growth. Yet there is at least some evidence of concern for a sustainable form of development in this landscape, indicated by outrage with a potential regression in human rights and equality with the retreat from the European Union, or a concern for equalities in the educational supply chain (Dawe 2017). Indeed, Wall (2017), reviewing the professional sphere of higher education, skills and work-based learning, called for action by practitioners and policy makers to respond to contemporary circumstances. These included (Wall, 2017: 311):

- Promote ways to further integrate notions of responsibility and sustainability into programmes of workplace learning - perhaps utilising the sustainable development goals as a discursive framework.

- Promote alternative, dynamic, holistic and humanistic conceptualisations of humans (which link to greater sense of well-being and connection to people and planet) in and through the various forms of work place learning opportunities and pedagogies.

- Promote the development and adoption of deeply emancipatory approaches to reflection and work based learning.

- Promote ways to further integrate notions of equality and diversity in reflection and work based learning.

- Promote ways of enabling workplace learners to sensitively raise and attempt to tackle workplace inequalities (whilst being sensitive to localised cultures and practices).

- Promote the further research and development of sustainable ways of developing skills and workplace learning in higher education which are appropriate for diverse groups such as 'older workers' and small and medium sized enterprises.

- Promote research and development into how well-being can be infused more directly into the sphere of higher education, skills and work based learning (including reflective practices).

- Promote ways of conceptualising practice and practice based problems which crossboundaries and which facilitate greater opportunities for radical insights

Although equality was a salient theme within these calls to action, it is only one of the United Nations' seventeen Sustainable Development Goals (United Nations, 2017), and as such, gives a strong indicator as to complexity of the sustainability aspiration (Wall 2017; Wall, 2018). The seventeen SDGs are (based on United Nations, 2017):

(1) end poverty in all its forms, everywhere;

(2) end hunger, achieve food security and improved nutrition;

(3) ensure healthy lives and promote well-being for all, at all ages;

(4) ensure equitable education and promote lifelong learning opportunities for all;

(5) achieve gender equality and empower all women and girls;

(6) ensure availability and sustainable management of water and sanitation for all;

(7) ensure access to affordable, reliable, sustainable and modern energy for all;

(8) promote sustained and inclusive employment, and decent work for all;

(9) build resilient infrastructure and foster innovation; 
(10) reduce inequality within and among countries;

(11) make cities and human settlements inclusive, safe, resilient and sustainable;

(12) ensure responsible and sustainable production and consumption;

(13) take urgent action to combat climate change and its impacts;

(14) conserve the oceans, seas and marine resources;

(15) protect and promote sustainable use of terrestrial ecosystems;

(16) promote peaceful and inclusive societies and accountable institutions; and

(17) strengthen the means of implementation through global partnerships.

A central tenet of this paper is that more needs to be done towards the sustainable development of workforces, organisations and wider economies, that is, that we need to promote a number of areas beyond economic focus in order to generate a more balanced societal growth. In line with this argument, this paper focuses on five key areas of interest to the University Vocational Awards Council, the leading independent body for the field of higher education, skills and work based learning in the UK, as well as the commissioner of the Higher Education, Skills and Work-Based Learning journal. These are summarised as: Apprenticeships and the role of HEIs; reform to technical education (including at Levels 4 and 5); productivity and skills; social mobility and widening participation; and the impact of Brexit on the future of skills. The structure of this article follows a discussion of each of these areas and then highlights promising future directions. Each of these aspects are now discussed in reference to the contemporary policy landscape and sustainable forms of development.

\section{Apprenticeships and the role of higher education institutions}

In the language of twenty first century skills, the variety of misconceptions and ideologies that created the centuries long held view of the academic and vocational divide still persist (Wall and Perrin 2015). In England and other countries such as Australia, vocational training has long been regarded as inferior to academic attainment; that "knowing" is more highly regarded than "doing" (Gribble et al, 2015). This is no less true of the arguments being applied to apprenticeships in England where there has been a renaissance in the uptake of apprenticeships in recent years with 491,000 apprenticeship starts at all levels in 2016/17 (Department for Education, 2018). While apprenticeship starts have historically been dominated by opportunities in low 'level' job roles in, for example health and adult social care, business administration and customer service, this is likely to change with the advent of new Degree Apprenticeships that do not just cross the academic and vocational divide but reframe our understanding of what it means to develop and accredit occupational and professional competence in and through the workplace (Lester et al, 2016; Rowe et al 2016).

Degree Apprenticeships, led by employer choice since 2015, have been and still are being developed in key public and private sector occupations including for graduate professions in nursing, policing, social work, teacher, engineering, digital technology and in leadership and management. Rather expectantly, but excitingly, higher education institutions of all sizes and types have responded positively to what has been a migration upwards in the skill level and professional occupational focus of apprenticeships. Over 100 higher education providers are now approved to deliver apprenticeships in England. Having suffered for generations from an academic vocational divide where vocational programmes were the poor relation and the choice for other people's children, it is now the case that through the UK Government's apprenticeship reforms, a clear policy focus and the hard work of universities, the skills system in England has those ranked among the foremost universities in the world now engaged in delivery. 
For UVAC the potential of having more than 100 higher education institutions engaged in apprenticeships is a significant milestone. Engaging world leading universities is good for the perception and brand of apprenticeships at this critical stage in a long reform process. The priority for Government must be to manage a skills system that engages both further and higher education in the design and creation of programmes that deliver a professionally competent and highly skilled workforce (Bravenboer and Lester, 2016) as not doing so impedes the development of new work-based progression routes through apprenticeships which open up access to under-represented cohorts of individuals to technical, professional and managerial occupations and, where appropriate, to professional body recognition.

At the same time as these positive developments and an ever-increasing evidence base of how higher education institutions are driving through this change (Rowe et al, 2016), there is still very little evidence of how sustainability and sustainable development are being embedded into these programmes of study (Wall et al 2017b; Wall and Hindley 2018, forthcoming). This may not be due to an overemphasis on the needs of employers, as there is evidence that organisations are recognising, to a greater or lesser extent, the need for sustainability and sustainability mindsets and perspectives to drive future business growth (Wall, 2017; Wall, 2018). Rather, it might be that higher education institutions themselves are requiring an even deeper exposure to these issues to stimulate new pedagogical innovations which tackle the more complex demands of sustainable development in the workplace.

These include, for example, new reflective methodologies for integrated thinking and working which move from 'reflective knowing' to 'difficult knowing' where the answers are not easy or clear cut (Akrivou and Bradbury-Huang, 2015; Wall et al 2018b, forthcoming; Wall and Meakin, 2018, forthcoming). Such a move needs us to consider moving from relevance to relating where higher education institutions need to impress the importance of particular issues for organisational sustainability in a wider complex environment.

\section{Reform to technical education}

England's long experience of reform and development in apprenticeships particularly at the higher skill level is partnered with unprecedented change in its vocational and technical education for more than a generation. Indeed, proposals for T levels, Institutes of Technology and the early stages of a review of technical / technician level education at Level 4 (Certificate of HE) and Level 5 (Foundation Degree) come at the same time as the announcement by the British Prime Minister of a year-long review of post- 18 education including higher education tuition fees (Department for Education, 2018). This is placing particular emphasis on the content of technical qualifications and alternatives to traditional full-time three-year degree programmes, varying fee levels and demonstrating the value added by different HE courses including higher and degree apprenticeships.

While there is certainly a need for an alternative to A levels, the design principles of and approach to $\mathrm{T}$ levels fail to understand the role of the Applied General in widening participation and supporting access to higher level study and has failed to define sufficiently the target cohort and whether or not they are a focus on students from disadvantaged backgrounds or a mainstream alternative to the A level. If $\mathrm{T}$ levels are intended to support progression to higher education and if $\mathrm{HE}$ is a customer of the T level learner, then HE must be fully engaged which at presently it is not wholly. For UVAC, ensuring progression opportunities to higher level learning for individuals with the ability and most importantly the aspiration, must be a high priority. 
The interplay between $\mathrm{T}$ levels and apprenticeships is also critical. The most noticeable outcome of the apprenticeship reforms is that employer demand for apprenticeships is moving upwards in level. T levels should provide a better opportunity for learning for the cohort who typify the general Level 2 apprentice (i.e. those who are employed in generic lower-level apprenticeships in dubious job roles such as in business administration and customer service) (Anderson, 2017). A Sutton Trust report (Fuller et al, 2017) recently described how many apprentices following Intermediate Apprenticeships tread water as their apprenticeship programme is no higher than their school or college attainment and so does not represent a stepping up in terms of skill development. This is a damning indictment of a skills system that currently measures its success on the quantum rather than the quality of apprenticeship provision. Similarly, T levels should develop skills reflective of the workplace and where appropriate be designed to articulate and support highly valued progression pathways to key apprenticeships where labour market information and employer led intelligence suggests there is a compelling need.

As developments with the apprenticeship system continue so does the Government aim to establish new Institutes of Technology (IoTs). At the end of 2017 the prospectus for IoTs was launched and encouraged further education, higher education and employers to collaborate to develop new approaches to delivering technical skills at Levels 4 and 5 (Department for Education, 2017a). In tandem, there is a review of Level 4 and 5 technical education (Department for Education (2017b) particularly from the perspective of progression from T levels, to tie with the Sainsbury Review Panel and its recommendations set out in the Post-16 Skills Plan (Department for Education, 2016). Such a landscape is an increasingly crowded space in skills policy terms.

So, where does the University Vocational Awards Council stand as the organisation representing higher education providers? From a UVAC perspective it is necessary to ensure that universities and higher education providers remain a recognisable partner and interested stakeholder by Government when positioning any new qualifications relative to other provision including apprenticeships. While employers are rightly outlined as central to the success of any national review of vocational and technical education and the requirement for occupational competence it is concerning that little or no reference is made to higher education.

What is even more significant in relation to sustainability and sustainable development is that there seems to be little dialogue or acknowledgement about how such concepts, skills or knowledge are explicitly or implicitly integrated into the curricula of the vocational educational supply chain, thereby building sustainability and sustainable development knowledge across a wide range of occupational settings (Wall and Hindley, 2018, forthcoming; Wall and Meakin, 2018, forthcoming). What sustainability learning content and pedagogical perspectives could be embedded earlier on in the supply chain so that these can be further deepened at higher education level? There is increasing promising work, for example, in the area of social innovation and social change work (Alden Rivers et al, 2015; Rivers et al 2015). How might such occupationally relevant capacities be integrated into our vocational base?

\section{Productivity and skills}

As the growth in interest in Higher and Degree Apprenticeships has manifested itself so has an argument that apprenticeships should retain its Level 2 focus and support young people enter the workforce, particularly those who have not achieved well under the schools system (Dawe, 2017). Dawe (2017:1) argues: 
Four months since the start of the reforms, one of the clear unintended consequences has been the negative impact on social equality of the young and most disadvantaged through a combination of different drivers impacting engagement and leading to a reduction in opportunities.

The apprenticeship levy wasn't introduced and imposed on employers in April 2017 to fund training provision that develops skills many would argue should have been developed through compulsory education. Nor was the apprenticeship levy introduced to fund programmes to tackle youth unemployment and those young people categorised as not in education, employment or training (NEET). There is a fundamental role for apprenticeships for 16 - 19-year-olds, but this role must be determined by employers on the basis of their need to develop their workforce and enhance business productivity.

The University Vocational Awards Council accepts that there are justifiable arguments for retaining apprenticeships in traditional craft occupations, especially in small businesses, such as butchers, chefs, and beauty professionals. However, if apprenticeships are doing what they are intended to do, then the assumption is that business will increase its productivity. If the purpose of apprenticeship is to raise productivity and enhance social mobility England's apprenticeship programme must realistically have a significant focus on higher level skills provision. To demonstrate the point, take the example of the largest single levy payer: the National Health Service (NHS). To suggest that the NHS should underspend or fail to recover its levy in total by supporting the funding of apprenticeships in the private sector is problematic. The logic here, clearly based on value judgements, is that apprenticeships in healthcare, particularly at the higher level and Degree Apprenticeships, should trump apprenticeships in hospitality, customer service and business administration.

Yet at the same time, this echoes the complex system wide effects of policy reform, at least in the transitional stage of adjustment to the wider system. Indeed, the new apprenticeship system have a major impact on the working lives of so many in the UK, and so it is crucially important to provide pedagogical content and structures which go beyond just a technical focus on workplace impact, and consider the wider systemic effects of that learning (Qu and Sun 2015). Such content and structures need to develop and embed values of and beliefs which speak to and inculcate societal predispositions to sustainability and sustainable development, such as to develop more complex learning capacities and the abilities to deal with multiple demands (Wall et al 2017b; Wall et al 2018, forthcoming; Wall and Meakin, 2018, forthcoming).

\section{Social mobility and widening participation}

An early and welcome aspect of the rise in Degree Apprenticeships is the potential impact on the social mobility agenda and increasing number of women entering STEM occupations (UVAC, 2017). These early indications are contrary to the concern that Degree Apprenticeships will be dominated by the middle classes or grabbed by young people with greater social, cultural and economic capital. From a University Vocational Awards Council standpoint, there needs to be a move to a position where Apprenticeships are seen as an aspirational choice for young people and adults from all backgrounds. With Degree Apprenticeships, higher education institutions and their partners are potentially unsettling and destabilising some of the social structures that have dominated the educational system. Together they are challenging the whole notion of the division between being academic and being vocational. Indeed, the scale and extent of university involvement so far has created a far more holistic focus around being occupationally competent (Crawford-Lee, 2018). 
From a social mobility standpoint, the argument is clear cut. Lower level Intermediate Apprenticeships do help many young people enter the labour market, but do we now not need clear work-based progression routes to higher level occupations, ideally through Higher and Degree Apprenticeships, for apprenticeships to make a major contribution to social mobility? The apprenticeship levy was primarily introduced to enhance business productivity and increase social mobility and employers' direct investment in apprenticeships should be encouraged and conducted on this basis. Shouldn't one of the ambitions of the apprenticeship reforms be an employer funded debt free route through apprenticeship to the professions where individual learners, particularly from disadvantaged backgrounds, earn while they learn? And if employers want to move away from some of the more generic Level 2 apprenticeship opportunities, will the T levels be a more appropriate route for those learners?

Of course, a change in the focus of apprenticeships is proving difficult for some providers, but it is UVAC's view that change will happen. The opportunities are, without doubt, challenging and substantial. Through the levy there is significantly more funding each year ( $40 \%$ or $£ 1$ bn more) than in the past for apprenticeship delivery. The UK Government is planning substantial investment in T levels, which in itself will provide yet another opportunity. The England wide apprenticeship market is also seeing both independent training providers and further educations colleges developing their presence in the Higher and Degree Apprenticeship market. The skills sector can and should also embrace this, too, rather than resist change, and therefore be at the forefront of developing the skills needed by the UK economy and to the benefit of social mobility?

As these changes develop, it is also a major opportunity to start embedding sustainability and sustainable develop as an inherently crucial dimension of what it means to be a professional, and to contribute to society. In relation to the levy, although the currently bounded freedom of organisations is valued in terms of training and development expenditure, could certain sustainability learning or outcomes be valued more than others? This would echo other actual or proposed policy changes which are working through the political sphere, such as (1) policy related to the banning of fossil fuel cars or (2) pay-back arrangements for consumers when they return drinking bottles. Indeed, such moves reflect the role of new and disruptive forms of critical reflection that are so important to sustainability and sustainable development (Wall 2016a; Wall 2016b).

\section{Impact of Brexit on the future of skills}

As the next few years unfold, Degree Apprenticeships seem to offer an attractive proposition for individuals and organisations to develop and build capabilities to tackle the complexities inherent in the political landscapes. For individuals, Degree Apprenticeships can be attractive as they offer a job and a salary from the start - and no student debt. For employers, Degree Apprenticeships offer an ideal solution to developing the occupational competence of both new and existing employees. And for universities and higher education providers, they offer a significant new way to engage with employers to meet their skill needs in the context of Brexit and the estimated new economic reality of leaving the European Union.

One impact of Brexit on the future of the Government's flagship skills programme, coupled with employers' shift in focus towards apprenticeship provision at degree level, is that the historic training provider base of apprenticeship delivery is no longer fit for purpose. In addition, England's funding body - the Education and Skills Funding Agency (ESFA) has not yet revised its systems sufficiently to appropriately engage the new providers needed. This is because the ESFA, despite its name, remains a schools and further education funding organisation with little understanding of higher education and has taken a "further education first" approach to the implementation of the Apprenticeships reforms (Anderson, 2018). 
Almost all ESFA apprenticeship systems deployed - procurement, contracting, data reporting, performance management, quality oversight - are based on further education and persist as a barrier to both employers and universities wanting to deliver Degree Apprenticeships. If Government systems continue to hinder employers' access to the apprenticeships, it could lead to less investment on workforce development. In effect, this then undermines the original intention of the introduction of the apprenticeship levy, and does so at a time when the norm in UK skills delivery is being challenged, when different ways of working are being sought, and when new ideas are being introduced, shaped and implemented.

In a post Brexit England, let us hope that our access to affordable electricity remains uninterrupted by the nuclear industry which is attempting to combat chronic skills shortages through investment in the nuclear scientist, nuclear engineer Degree Apprenticeship. In UVAC's view the future for HE engagement in apprenticeships and the technical and professional skills system is positive if the UK Government ensures the employer remains central to developments and they are unhindered in deciding where to invest in workforce development. If Government commits to the apprenticeship reforms as intended, higher education will play a pivotal role in ensuring Degree Apprenticeships open-up and support progression to professional and more highly paid occupations to those who have not had such opportunities before and compliment the historic full-time university route. Only then can the two main drivers of Apprenticeships - raising productivity and enhancing social mobility be realised. But we need to do more to raise the game on integrating sustainability and sustainable development into the vocational and educational landscapes across the UK to take leaps in creating sustainable futures for all involved (as well as those not yet involved).

\section{Promising directions}

The Chartered Institute of Personnel \& Development, the oldest professional body for people and capability, recently released a Manifesto for Work which said (CIPD, 2017a, p. 2):

We believe we must work towards putting people much more at the heart of business thinking and practice... We need to invest in them, engage them, and lead from the principles that good work is purposeful, good work is safe, inclusive and good for our well-being, and that good work exists for the long-term benefit of individuals, organisations and society. That work can, and should, be a force for good, for all.

Equally, in March 2018, collective action was making noise, literally, about the need to do more. The United Nations' (2018) reported:

Multiple voices and solidarity are the success ingredients for global action: this was the main takeaway from the last day of the Global Festival Action for Sustainable Development. More than 1,500 participants from more than 100 countries convened at the Festival, hosted by the United Nations SDG Action Campaign.

With this in mind, the University Vocational Award Council agrees with the CIPD and the United Nations, and to this end, there are a number of promising directions:

1. We need to export and promote Degree Apprenticeships as a way of embedding knowledge with the workplace beyond England where there is growing interest such as in Australia, New Zealand and the United States. Though, as experienced in some of these countries, the commitment to developing inclusive workplaces and spaces for apprentices 
needs to be recognised and developed (Gribble et al, 2015; Wall, 2017; Wall et al 2017c). This requires wider governmental actions to shape workplaces.

2. From a social mobility perspective, Higher and Degree Apprenticeships which provide a new debt free route to the professions and higher level occupations for under-represented groups must be a priority. Any new payback arrangements must not disproportionately disadvantage certain groups, as we have witnessed in some other countries (Wall et al 2018a, forthcoming).

3. Apprenticeship and skills funding should be allocated to where it will have most impact on raising productivity and opening up new progression routes to professional and higher level occupational roles - occupations that have not previously been encompassed by apprenticeships before. However, productivity does not and should not take precedent over the health and wellbeing of the current or future workforces (Wall and Jarvis, 2015; Wall et al 2018b, forthcoming).

4. We must also ensure a full suite of Degree Apprenticeships are available across England to support the Government's social mobility objectives and create new gateways to the professions for under-represented cohorts of learners. Embedding forms of critical reflection and action which are particularly adept at spotting and addressing inequality in the workplace should be valued and prioritised (Wall, 2016a; Wall, 2016b). We should commit to making this aspiration part of what it means to contribute as a professional in any vocation.

\section{References}

Akrivou, K. and Bradbury-Huang, H. (2015), "Educating integrated catalysts: transforming business schools toward ethics and sustainability", Academy of Management Learning \& Education, Vol. 14 No. 2, pp. 222-240.

Alden Rivers, B., Armellini, A. and Nie, M. (2015), "Embedding social innovation and social impact across the disciplines: identifying 'changemaker' attributes", Higher Education, Skills and Work-Based Learning, Vol. 5 No. 3, pp. 242-257.

Anderson, A. (2017) To boost social mobility we need more degree apprenticeships, available at: https://feweek.co.uk/2017/07/20/to-boost-social-mobility-we-need-moredegree-apprenticeships/, accessed $22^{\text {nd }}$ April 2018.

Anderson, A (2018) Engage better with universities or England's apprenticeship programme will fail, available at: https://www.timeshighereducation.com/opinion/engage-betteruniversities-or-englands-apprenticeship-programme-will-fail, accessed $22^{\text {nd }}$ April 2018.

Bravenboer, D. and Lester, S. (2016). Towards an integrated approach to the recognition of professional competence and academic learning. Education + Training, 58(4), 409421.

Crawford-Lee, M. (2018) Mixed Fortunes and Milestones for Universities in Apprenticeship Delivery, available at: https://wonkhe.com/blogs/mixed-fortunes-and-milestonesuniversities-in-apprenticeship-delivery/, accessed $29^{\text {th }}$ March 2018.

Dawe, M. (2017) The unintended consequences of the Apprenticeship Reforms on the social equality of the young and the most disadvantaged. Time to act before a generation is lost, London, Association of Employment and Learning Providers. Available at https://www.aelp.org.uk/media/1454/aelp-submission-42-apprenticeships-as-driverof-social-mobility.pdf, accessed $29^{\text {th }}$ March 2018. 
Department for Education (2016) Post-16 Skills Plan, available at https://www.gov.uk/government/uploads/system/uploads/attachment_data/file/536043 /Post-16_Skills_Plan.pdf, accessed 29 $9^{\text {th }}$ March 2018.

Department for Education (2017a). Institutes of technology prospectus, available at https://www.gov.uk/government/publications/institutes-of-technology-prospectus, accessed $29^{\text {th }}$ March 2018.

Department for Education (2017b). Level 4 \& 5 technical education to be reviewed, available at https://www.gov.uk/government/news/level-4-5-technical-education-to-bereviewed, accessed $29^{\text {th }}$ March 2018.

Department for Education (2018) FE data library: apprenticeships, London, Department for Education, available at https://www.gov.uk/government/statistical-data-sets/fe-datalibrary-apprenticeships, accessed $29^{\text {th }}$ March 2018.

Department for Education (2018) Prime Minister launches major review of post-18 education, available at https://www.gov.uk/government/news/prime-ministerlaunches-major-review-of-post-18-education, accessed 29 $9^{\text {th }}$ March 2018.

Fuller, A., Unwin, L., Cavaglia, C., McNally, S., and Ventura, G. (2017) Better Apprenticeships: Access, quality and labour market outcomes in the English apprenticeship system, London, Sutton Trust.

Gribble, C., Blackmore, J. and Rahimi, M. (2015), "Challenges to providing work integrated learning to international business students at Australian universities", Higher Education, Skills and Work-Based Learning, Vol. 5 No. 4, pp. 401-416

Lester, S., Bravenboer, D., and Webb, N. (2016) Work-integrated degrees: Context, engagement, practice and quality, Gloucester, Quality Assurance Agency.

Rivers, B.A., Armellini, A., Maxwell, R., Allen, S. and Durkin, C. (2015), "Social innovation education: towards a framework for learning design", Higher Education, Skills and Work-Based Learning, Vol. 5 No. 4, pp. 383-400.

Rowe, L., Perrin, D. and Wall, T. (2016), "The Chartered Manager Degree Apprenticeship: trials and tribulations", Higher Education, Skills and Work-Based Learning, Vol. 6 No. 4, pp. 357-369.

Sun, Q. and Kang, H. (2015), "Infusing work-based learning with Confucian principles: a comparative perspective”, Higher Education, Skills and Work-Based Learning, Vol. 5 No. 4, pp. 323-338.

United Nations (2017), “The sustainable development goals", United Nations, available at: www.un.org/sustainabledevelopment/sustainable-development-goals/ (accessed 29 March 2018).

United Nations (2018) "1,500 participants make noise at the Global Festival of Action for the world to hear - Day 2 and 3 wrap up", available at http://www.un.org/sustainabledevelopment/blog/2018/03/1500-participants-makenoise-global-festival-action-world-hear-day-2-3-wrap/ (accessed 30 March 2018).

UVAC (2017) Reflections and lessons from the apprenticeship journey - Case studies from Higher Education apprenticeship delivery, Bolton, UVAC, available at https://uvac.ac.uk/wp-content/uploads/2017/11/Case-Studies-UVAC-SDNNovember-2017-v3-0.pdf, accessed $29^{\text {th }}$ March 2018.\#

Wall, T. (2016a) Provocative Education: From Buddhism for Busy People® to Dismal Land®, Studies in Philosophy and Education, March.

Wall, T. (2016b), “Žižekian ideas in critical reflection: the tricks and traps of mobilising radical management insight", Journal of Work-Applied Management, Vol. 8 No. 1, pp. 5-16. 
Wall, T. (2017) A manifesto for higher education, skills and work-based learning: through the lens of The Manifesto for Work, Higher Education, Skills and Work-Based Learning, 7 (3), 304-314.

Wall, T. (2018) Infusing ethics into leadership learning \& development, in Knights, J. et al (Ed.), Leading Beyond the Ego: How to Become a Transpersonal Leader, London, Routledge.

Wall, T. and Jarvis, M. (2015), "Business schools as educational provocateurs of productivity via interrelated landscapes of practice", Chartered Association of Business Schools, London.

Wall, T. and Perrin, D. (2015), Slavoj Žižek: A Žižekian Gaze at Education, Springer, London.

Wall, T., Bellamy, L., Evans, V., and Hopkins, S. (2017a) Revisiting impact in the context of workplace research: a review and possible directions, Journal of Work-Applied Management, 9 (2), pp.95-109.

Wall, T., Clough, D., Österlind, E., and Hindley, A. (2018a, forthcoming). Conjuring A Spirit for Sustainability: a review of the socio-materialist effects of provocative pedagogies, in Leal Fihlo, W. (ed) Sustainability in Higher Education - World Sustainability Series, Springer.

Wall, T., Giles, D., and Stanton, T. (2018b, forthcoming) Service-learning and academic activism: a review, prospects, and a time for revival, in Billingham, S. (ed) Access to Success and Social Mobility through Higher Education: A Curate's Egg?, The Great Debates in Higher Education Series, London, Emerald.

Wall, T., Hindley, A., Hunt, T., Peach, J., Preston, M., Hartley, C., and Fairbank, A. (2017b). Work-based learning as a catalyst for sustainability: a review and prospects, Higher Education, Skills and Work-Based Learning, 7 (2), 211-224.

Wall, T. and Hindley, A. (2018, forthcoming). Work integrated learning for sustainability education, in Leal Filho, W. (Ed) Encyclopedia of Sustainability in Higher Education, Cham Switzerland, Springer.

Wall, T. and Meakin, D. (2018, forthcoming). Reflective Practice for sustainable development, in Leal Filho, W. (Ed) Encyclopedia of Sustainability in Higher Education, Cham Switzerland, Springer.

Wall, T., Tran, L.T. \& Soejatminah, S. (2017c). Inequalities and agencies in workplace learning experiences: international student perspectives, Vocations and Learning, 10 (2), pp 141-156. 